Lowell, F.C. (1942) Evidence for the existence of two antibodies for crystalline insulin. Proc. Soc. exp. Biol. (N.Y.). 50, 313.

MirSKY, I.A. \& Kawamura, K. (1966) Heterogeneity of crystalline insulin. Endocrinology, 78, 1115.

Moloney, P.J. \& Coval, M. (1955) Antigenicity of insulin; diabetes produced by specific antibodies. Biochem. J. 59, 179.

Moloney, P.J., Aprile, M.A. \& Wilson, S. (1964) Sulfated insulin for treatment of insulin-resistant diabetics. J. New Drugs, 4, 258.

MowbRAY, R.R. de (1966) Risk of changing from ox to pig insulin. Letter. Lancet. ii, 1027.

OAKLeY, W.G., Jones, V.E. \& CUNLIFFe, A.C. (1967) Insulin resistance. Brit. med. J. i, 134.

Penchev, I., Andeev, D. \& Ditzov, S. (1968) Insulinprecipitating antibodies in insulin-treated and untreated diabetic patients. Diabetologia, 4, 164.

Rubenstein, A.H., Cho, S. \& Steiner, D.F. (1968) Evidence for proinsulin in human urine and serum. Lancet, $\mathbf{i}, 1353$.

Shipp, J.C., Russell, R O., Steinke, J., Mitchell, M.L. \& HADLEY, W.B. (1961) Insulin resistance with high levels of circulating insulin-like activity demonstrable in vitro and in vivo. Diabetes, $10,1$.

Shipp, J.C., Cunningham, R.W., Russell, R.O. \& Marble, A. (1965) Insulin resistance: clinical features, natural course and effects of adrenal steroid treatment. Medicine (Baltimore), 11, 165.
Silverman, J.L. (1963) Eosinophil infiltration in the pancreas of infants of diabetic mothers. Diabetes, 12, 528.

Smelo, L.S. (1948) Insulin resistance. Proc. Amer. Diabetes Ass. 8, 77.

Smith, L.F. (1966) Species variation in the amino-acid sequence of insulin. Amer. J. Med. 40, 662.

Tchobroutsky, G. (1966) Insulino-résistance, anti-corps anti-insulin chez l'homme. Path. Biol. 14, 619.

Wilson, S., APrile, M.A. \& SASAKI, L. (1967) The antigenic loci of insulin. Can. J. Biochem. 45, 1135.

Wilson, S., Dixon, G.H. \& WardlaW, A.C. (1962) Resynthesis of cod insulin from its polypeptide chains and preparation of cod-ox 'hybrid' insulins. Biochim. Biophys. Acta (Amst.), 62, 382.

Wright, P.H. (1959) Production of acute insulin deficiency by administration of insulin antiserum. Nature (Lond.), 183, 829.

WRIGHT, P.H. (1961) The production of experimental diabetes by insulin antibodies. Amer. J. Med. 31, 892.

YAlOw, R.S. \& Berson, S.A. (1957) Apparent inhibition of liver insulinase activity by serum and serum fractions containing insulin-binding antibody. J. clin. Invest. 36, 648.

Yamamoto, M., Kotaki, A., OKuyama, T. \& Satake, K. (1960) Two different insulins from langerhans islet of bonito fish. J. Biochem. 48, 84.

Young, B.A. \& Kellock, T.D. (1966) Potential hazard for diabetics. Letter. Lancet, ii, 1010.

\title{
Virus infections in patients with malignant disease
}

\author{
R. B. HEATH \\ M.D. \\ Senior Lecturer in Virology, St Bartholomew's Hospital, \\ London, E.C.1
}

IT IS THE purpose of this short review to discuss the unusual manifestations of ordinary virus infections which are sometimes seen in malignant disease. As would be expected, these mainly occur in patients with malignant disease of the reticulo-endothelial system in which there is now abundant evidence that humoral and cellular immunity are depressed (Heath, Fairley \& Malpas, 1964; Schier et al., 1956). No attempt will be made to enter into the debate on whether these or other malignant diseases can be induced by viruses. However, should malignant disease of the reticulo-endothelial system subsequently be proved to have a viral aetiology, then we shall have an interesting pathogenetic situation in which a malignant disease is not only depressing immune processes active against tumour specific antigens, but is also depressing mechanisms concerned with elimination or control of the inducing agent. It is doubtful how important the latter will prove to be, since current work on viral oncology has generally indicated that persistence of virus in an active form is not required for the maintenance of the malignant process.

\section{Pathogenesis of virus infections}

In general, virus infections are of two main types. Firstly, there are those which remain localized at the portal of entry such as the common viral diseases of the upper respiratory tract. Then there are the infections where the virus first replicates at the portal of entry and then spreads via the blood stream causing further infection of distant organs. These viraemic diseases are recognized by signs and symptoms resulting from virus destruction of the cells of specific target organs. Typical infections of this kind are smallpox, poliomyelitis and yellow fever in which cellular destruction occurs in cells of the skin, anterior horn cells and liver, respectively.

Infection at the target organ, whether this be at the portal of entry or elsewhere, is characteristically short-lived. Persistent active infection of a tissue of the kind seen in bacterial diseases such as 
tuberculosis, rarely occurs with viruses although cytomegalovirus infection and rubella infection of the foetus can be cited as examples of this kind. The termination of infection at the target organ is undoubtedly a complex but generally highly efficient process, which is not clearly understood at present. The cells damaged by virus in an infected tissue induce an inflammatory response, and the raised temperature, acidity, and lowered oxygen tension of this response will all tend to restrict further replication of the virus. Interferon, the natural antiviral substance, which is produced in virus-infected cells, is now generally regarded as being the most important factor in terminating primary virus infections.

It is possible that antibody plays some part in the virus eradication process but many regard its role as relatively unimportant since it is not usually detected in the tissues until after the virus has disappeared. Few, however, dispute the importance of antibody in preventing second infections, but here again, it must be remembered that most patients with hypogammaglobulinaemia develop normal immunity after infections with common viruses. The defence mechanisms do not always completely eradicate virus from the tissues; for example, it is well-known that herpes simplex, herpes zoster and adenoviruses can remain in an undetectable (latent) form in the tissues for many years. Latency can, of course, only be recognized if it is possible to reactivate the virus from its resting state.

It is a characteristic of nearly all virus infections that mononuclear cells are present in large numbers in the accompanying inflammatory exudate, and it is presumed that they play an important part in the virus eradication process. It is possible that these cells are important interferon producers since it has been shown that blood lymphocytes are capable of producing large amounts of this substance (Gresser, 1961). Again, it is well-known that some of these mononuclear cells will be the precursors of antibody producing cells (Leduc et al., 1955). It will be clear then, that any neoplastic disease of the reticuloendothelial system (which either reduces the number of lymphocytes or impairs their function) is likely to seriously interfere with antiviral defence mechanisms. In attempting to assess the effect that these diseases have on virus infections, one encounters a major difficulty. These malignant diseases are frequently treated by radiotherapy, with cytotoxic drugs or steroids, and these forms of treatment can on their own depress immune and other defence mechanisms. Consequently, it is often very difficult to decide whether it is the neoplastic disease itself or the treatment that is responsible for the effect on the virus infection. Although these various treatments act in different ways, there is, so far, no evidence that any one of them is more effective than another in altering the course of virus infections. Because of this, the term 'treated', without further specification, will be used in this article to refer to any of the above-mentioned treatments.

\section{Vaccinia virus}

Patients with reticulosis and those being treated with immunosuppressive drugs should only be vaccinated against smallpox in exceptional circumstances (World Health Organization Report, 1964). The reason for this is that these patients are especially likely to develop complications such as generalized vaccinia and vaccinia necrosum. The latter condition is fortunately very rare since in the absence of specific antiviral therapy it is invariably fatal. It is of interest that three of the twenty-three adult cases reported by Kempe (1960) occurred in patients being treated for leukaemia. This complication can occur in untreated leukaemias and has been the presenting feature of one case (Neff et al., 1967).

\section{Varicella-zoster virus}

It is now well established that herpes zoster and chickenpox are caused by the same virus and it is thought that the zoster infection is the result of reactivation of virus which has remained latent in the patient since the primary infection. Because these diseases have such well-defined clinical features, there is now a considerable amount of information on their modification in patients with disease of the reticulo-endothelial system. It is, for example, wellknown that herpes zoster occurs with increased frequency in these patients. Shanbrom, Miller \& Haar (1960) observed 303 patients with various forms of reticulosis for a period of 2 years, and noted that twenty-four $(7.9 \%)$ developed zoster. Most of these infections occurred in patients with Hodgkin's disease, chronic lymphatic leukaemia, lymphosarcoma and multiple myeloma, but only two cases occurred in patients with chronic granulocytic leukaemia. These authors also state that during this same time they did not see a single case of zoster in a further eighty-two cases of acute leukaemia. The distribution of zoster in these patients is of interest since it correlates well with the distribution of defective humoral immunity in patients with reticulosis (Heath et al., 1964). It is also of interest that four of the above cases were not being treated at the time of onset of the zoster infection, which suggests that the disease itself rather than the treatment was responsible for the recurrence.

The disease in these patients is often of the more serious disseminated form. Merselis, Kay \& Hook (1964) reported seventeen cases of this kind. All of these patients were being treated with corticotrophin and eleven had some form of reticulosis. 
Chickenpox, the primary infection with this virus, can follow a normal course in leukaemia particularly if the patient is in remission and treatment is stopped at the onset of the virus infection (Bodey, McKelvey \& Karon, 1964). However, there are many records of severe and even fatal cases of this infection occurring in patients with leukaemia. Pinkel (1961) has described four cases in children under treatment; two of these were fatal and one had an unusually prolonged illness. Finkel (1960) described forty-four cases of varicella occurring in patients on steroids. In this series, there were six deaths, and in five of these, the underlying disease was leukaemia.

Appraisal of these studies clearly shows that patients receiving treatment for malignant disease of the reticulo-endothelial system have difficulty in dealing with the primary infection with varicellazoster virus and also that they have defective means of keeping this virus in its latent form.

\section{Measles virus}

There is very little information on infections caused by this common virus in patients with malignant disease of the reticulo-endothelial system and therefore one must assume that they usually follow a normal course. There are, however, a few records of unusual and often particularly severe measles infection in patients with these diseases. Mitus et al. (1959) have described four cases of giant cell pneumonia in leukaemic children being treated with methotrexate and in two of these death was attributed to the viral pneumonia. These same workers have also reported a further fatal case in a leukaemic child that had been vaccinated with an attenuated strain of this virus (Mitus et al., 1962). This case, together with the cases of vaccinia necrosum referred to above, stress the fact that the terms attenuated and avirulent are only applicable to viruses infecting hosts with normal defence mechanisms.

\section{Cytomegalovirus}

This is a common virus which infects about half of the population by the age of 35 years. Infants infected congenitally with this virus are frequently seriously affected but infection in older children and adults is usually asymptomatic. Cytomegalovirus produces characteristic intranuclear inclusions in infected cells and these so-called 'owl-eye' inclusions are so distinctive that histologists were able to recognise the infection-known as cytomegalic inclusion disease-long before techniques were available for virus isolation. Review of the early literature on this disease shows that most of the adult cases occurred in patients with disease of the reticulo-endothelial system. The underlying disease in these cases has usually been malignant and was being treated. The characteristic inclusions were seen in the cells of many organs but were most frequently seen in the lungs where they were associated with pneumonitis (Peace, 1958; Symmers, 1960).

Evidence from studies in which the more sensitive and precise isolation techniques have been employed is unfortunately conflicting. Hanshaw \& Weller (1961) were able to isolate cytomegalovirus from the urine of four out of fifty leukaemic children but no healthy controls were included in this series. Benyesh-Melnick, Dessy \& Fernbach (1964) found an even higher incidence of urinary secretion of this virus in leukaemic children but found the same incidence in their controls. The reason for the discrepancy between these two reports is not clear but is possibly due to differences in testing procedures. A recent study has indicated that cytomegalovirus can be isolated from about one-third of adult patients suffering from some form of reticulosis and all but one of these patients was receiving treatment at the time (Duvall et al., 1966). In this series no isolations were made from normal controls.

Considering all the evidence, it seems certain that cytomegalovirus replicates more extensively in patients with malignant disease of the reticuloendothelial system, and is possibly more pathogenic in these patients.

\section{Other virus infections}

There is so far little evidence that malignan disease of the reticulo-endothelial system has any adverse effect on virus diseases other than those referred to above. It is theoretically possible that they might, in fact, benefit virus infections of the central nervous system since it has been postulated that some of these infections are not caused primarily by virus destruction but by immune processes resulting from the infection (Webb \& Gordon Smith, 1966). There is no evidence that enterovirus infections are more severe in patients with malignant disease although it should be noted that coxsackie viruses will only replicate in adult mice if the animals have been treated with steroids. Similarly, there is little evidence that patients with these malignant diseases are more susceptible to the common viral infections of the upper respiratory tract or that these infections are more serious. However, these minor ailments are very difficult to assess quantitatively particularly when compared to the diseases described above. We have recently obtained evidence that the cytotoxic drug, cyclophosphamide, can convert a simple 'signless' parainfluenza infection of the respiratory mucous membrane of mice into a fatal pneumonic illness (Robinson, Cureton \& Heath, 1969). In view of this, it would be useful to study common colds and similar illnesses in patients with malignant disease of the reticulo-endothelial system since these 
common infections frequently predispose to more serious bacterial disease of the chest.

\section{Conclusions}

It is now clear that many virus infections can be abnormally severe in patients with malignant disease, particularly if there is involvement of the reticuloendothelial system and the patient is receiving antineoplastic treatment. The abnormal virus infections in these conditions can be of two kinds. Firstly, there are the more severe primary infections or there is an increase in the frequency, as well as severity, of infections caused by reactivated latent viruses.

Since humoral and cellular immune processes are known to be depressed in certain reticuloses, it is tempting to assume that the underlying disease is at least partly responsible for the increased susceptibility to these infections. Direct evidence for this assumption is extremely difficult to obtain because these patients are almost invariably receiving treatment which can itself reduce immune and probably non-immune defence mechanisms. Nevertheless, it is most likely that the untreated malignant disease has some effect on the infection and support for this comes from some of the cases referred to above, for example, some of the zoster infections reported by Shanbrom et al. (1960), and the case of vaccinia necrosum referred to by Neff et al. (1967), all of which occurred in untreated patients.

There is now no doubt that many forms of cancer treatment increase susceptibility to virus infections. For example Haggerty \& Eley (1956) have recorded cases of fatal varicella in patients treated with cortisone and in only one case was the underlying condition malignant. Further evidence has been obtained from studies of infection in patients undergoing homotransplantation surgery, since immunosuppression in these patients is obtained by high dosage of drugs which are either the same or very similar to those used for the treatment of malignant disease. Preliminary investigations on these patients have indicated that they are particularly susceptible to virus infections. Hill et al. (1967) have recently reported on sixty fatal cases that had undergone this type of surgery. Evidence of cytomegalovirus infection was obtained in half of these cases and there was one zoster infection. It was of interest that they also observed cases of hepatitis and pancreatitis which were probably of viral aetiology.

Further studies employing present day virological techniques will more fully define the dangers of these infections in patients with malignant disease. Such studies are not only required to enable clinicians to appraise the risks of anti-neoplastic therapy more adequately but should provide valuable information on what are perhaps somewhat belated, but nevertheless highly efficient, antiviral mechanisms.

\section{References}

Benyesh-Melnick, M., Dessy, S.I. \& Fernbach, D.J. (1964) Cytomegaloviruria in children with acute leukaemia and in other children. Proc. Soc. exp. Biol. (N.Y.), 117, 624.

Bodey, G., McKelvey, E. \& Karon, M. (1964) Chickenpox in leukaemic patients-factors in prognosis. Pediatrics, 34, 562.

Duvall, C.P., Casazza, A.R., Grimley, P.M., Carbonne, P.P. \& ROWE, W.P. (1966) Recovery of cytomegalovirus from adults with neoplastic disease. Ann. intern. Med. 64, 531.

FinKel, K.C. (1961) Mortality from varicella in children receiving adrenocorticosteroids and adrenocorticotrophin. Pediatrics, 28, 436.

Gresser, I. (1961) Production of interferon by suspensions of human leucocytes. Proc. Soc. exp. Biol. (N.Y.), 108, 799.

HAGGERTY, R.J. \& ELEY, R.C. (1956) Varicella and cortisone. Pediatrics, 18, 160.

HANSHAW, J.B. \& WelleR, T.H. (1961) Urinary excretion of cytomegaloviruses by children with generalised neoplastic disease. J. Pediat. 58, 305.

Heath, R.B., Fairley, G.H. \& MalPas, J.S. (1964). Production of antibodies against viruses in leukaemia and related diseases. Brit. J. Haemat. 10, 365.

Hill, R.B., Dahrling, B.E., Starzl, T.E. \& Rifkind, D. (1967) Death after transplantation. An analysis of sixty cases. Amer. J. Med. 42, 327.

KEMPE, C.H. (1960) Studies on smallpox and complications of smallpox vaccination. Pediatrics, 26, 176.

Leduc, E.H., Coons, A.H. \& Connolly, J.M. (1955) Studies on antibody production. II. the primary and secondary responses in the popliteal lymph node of the rabbit. J. exp. Med. 102, 61 .

Merselis, J.G., KAYE, D. \& Hook, E.W. (1964) Disseminated herpes zoster. Arch. intern. Med. 113, 679.

Mitus, A., Enders, J.F., Craig, J.M. \& Holloway, A. (1959) Persistence of measles virus and depression of antibody formation in patients with giant-cell pneumonia after measles. New Engl. J. Med. 261, 882.

Mitus, A., Holloway, A., Evans, A.E. \& Enders, J.F. (1962). Attenuated measles vaccine in children with acute leukaemia. Amer. J. Dis. Child. 103, 413.

NefF, J.M., Levine, R.H., Lane, J.M., Ager, E.A., Moore. H., Rosenstein, B.J., Millar, J.D. \& Henderson, D.A, (1967) Complications of smallpox vaccination United States 1963. II. Results obtained by four statewide surveys. Pediatrics, 39, 916.

PEACE, R.J. (1958) Cytomegalic inclusion disease in adults. A complication of neoplastic disease of the haemopoietic and reticulohistiocytic systems. Amer. J. Med. 24, 48.

PINkel, D. (1961) Chickenpox and leukaemia. J. Pediat. 58, 729.

Robinson, T.W.E., Cureton, R.J.R. \& Heath, R.B. (1969) The effect of cyclophosphamide on Sendai virus infection of mice. J. gen. Microbiol. (In press).

Schier, W.W., Roth, A., Ostroff, G. \& Schrift, M.H. (1956) Hodgkin's disease and immunity. Amer. J. Med. 20, 94.

Shanbrom, E., Miller, S. \& HaAR, H. (1960) Herpes zoster in haematologic neoplasias: some unusual manifestations. Ann. intern. Med. 53, 523.

Symmers, W.St C. (1960) Generalised cytomegalic inclusion -body disease associated with pneumocystis pneumonia in adults. J. clin. Path. 13, 1.

WebB, H.E. \& GoRdon SMith, C.E. (1966). Relation of immune response to development of central nervous system lesions in virus infections of man. Brit. med. J. ii, 1179.

World Health Organization (1964) Technical Report Series No. 283. 